
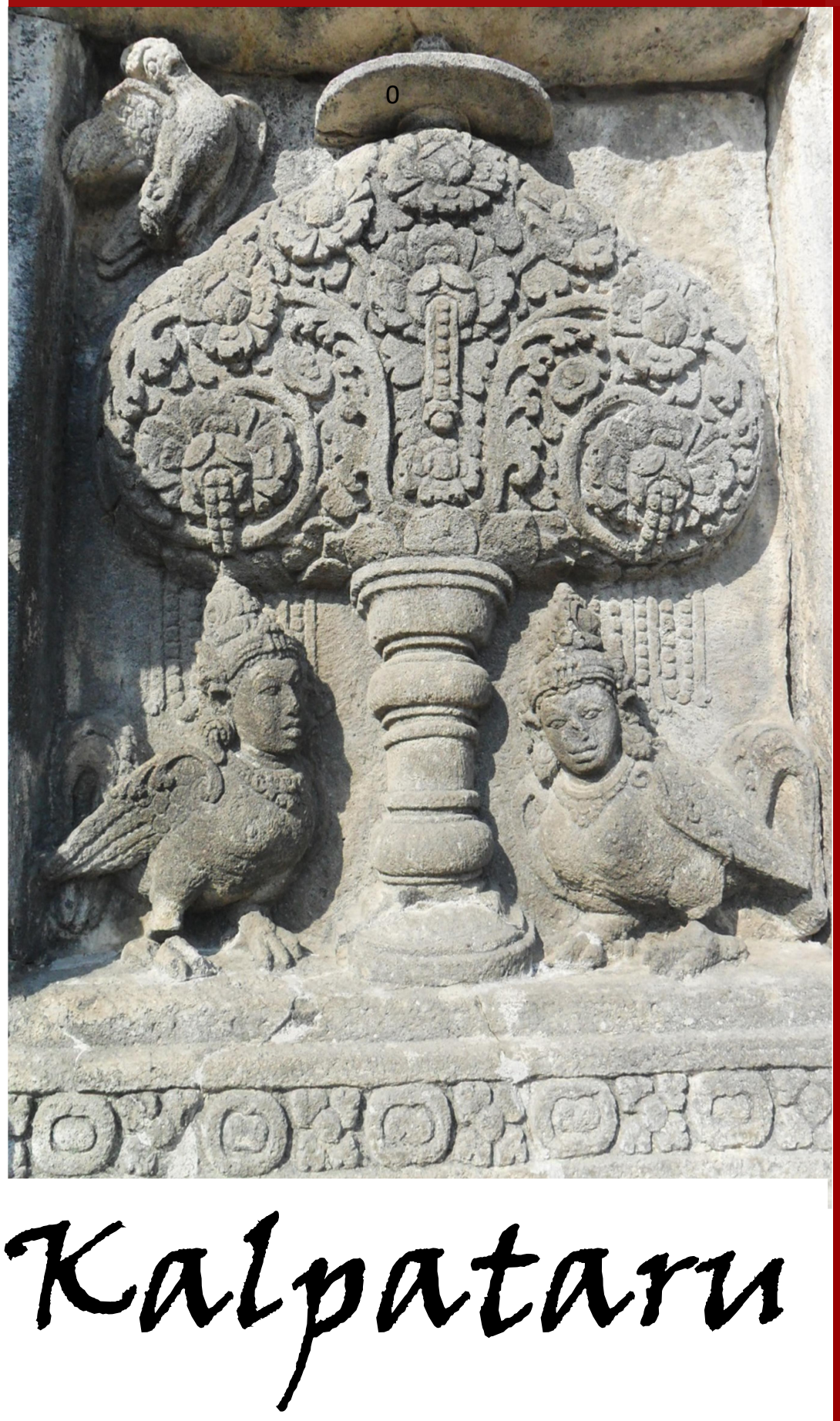

\author{
JURNAL SEJARAH DAN \\ PEMBELAJARAN SEJARAH
}

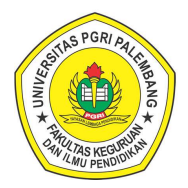

Program Studi Pendidikan Sejarah Jurusan Pendidikan IPS

Fakultas Keguruan dan IImu Pendidikan Universitas Persatuan Guru Republik Indonesia Palembang
Pengaruh Model Pembelajaran Student Facilitator and Explaining Terhadap Hasil Belajar Siswa Pada Mata Pelajaran Sejarah Kelas $X$ di SMA Negeri 3 Palembang

Sarinah, Nur Ahyani, Ahmad Zamhari

Pengaruh Model Pembelajaran Berbasis Masalah (PBM) Terhadap Hasil Belajar Siswa Pada Mata Pelajaran IPS Terpadu (Sejarah) Kelas VIII di SMP Negeri 2 Palembang

Neka Dapistri, Nur Ahyani, Ahmad Zamhari

Penerapan Media Pembelajaran Menggunakan Google Earth Dalam Materi Kondisi Masyarakat Indonesia Pada Masa Penjajahan Terhadap Hasil Belajar Siswa Pada Mata Pelajaran IPS Terpadu di SMP Quraniah Palembang

Tri Nur Ariani, Eva Dina Chairunisa, Ida Suryani

Perkembangan Sosial Budaya Suku Jawa di Desa Kapasan Tegalrejo BK $X$ Kecamatan Belitang Kabupaten Ogan Komering Ulu Timur Sebagai Sumber Pembelajaran Sejarah di SMA Muhammadiyah 2 Karang Tengah

Ratna Puspita Dewi, Sukardi, Mirza Fansyuri

Pengembangan E-Modul Pembelajaran Sejarah Tokoh-Tokoh Pembangunan

Susi Susanti, Eva Dina Chairunisa

Peran Pendidikan Sejarah Dalam Membentuk Karakter Bangsa

Sukardi, Jeki Sepriady

Sejarah Pengajaran Mantra Melayu di Tengah Perubahan Masyarakat Besemah Muhamad Idris, Eva Dina Chairunisa, Jeki Sepriady

Pengembangan Media Audio Visual Sejarah Kolonialisme Barat di Indonesia Materi Benteng Marlborough Bengkulu Hamza Kurniawan 


\section{Kalpataru}

Jurnal Sejarah dan Pembelajaran Sejarah

Volume 6, Nomor 2, Desember 2020

\section{Chief Editor}

Drs. Sukardi, M.Pd.

\section{Editor}

Dr. Muhamad Idris, M.Pd.

Eva Dina Chairunisa, M.Pd.

Jeki Sepriady, S.Pd.

\begin{tabular}{ll}
\multicolumn{2}{c}{ Reviewer } \\
Dr. Tahrun, M.Pd. & (Universitas PGRI Palembang) \\
Drs. Supriyanto, M.Hum. & (Universitas Sriwijaya Palembang) \\
Dra. Retno Purwati, M.Hum. & (Balai Arkeologi Sumatera Selatan) \\
Dr. Nor Huda Ali, M.Ag., M.A. & (Masyarakat Sejarawan Indonesia Sumsel) \\
Dr. Budi Agung Sudarman, S.S., M.Pd. & (Balai Bahasa Provinsi Sumatera Selatan) \\
Dr. Purmansyah, M.A. & (Universitas Muhammadiyah Palembang)
\end{tabular}

Alamat Redaksi

Program Studi Pendidikan Sejarah

Fakultas Keguruan dan IImu Pendidikan Universitas PGRI Palembang

Telp. 0711-510043

Email: jurnalkalpatarusejarah@gmail.com

Website: https://jurnal.univpgri-palembang.ac.id/index.php/Kalpa 


\section{Kalpataru}

JURNAL SEJARAH DAN

PEMBELAJARAN SEJARAH

Terbit dua kali setahun pada Juli dan Desember

Diterbitkan oleh:

Program Studi Pendidikan Sejarah

Jurusan Pendidikan IPS

Fakultas Keguruan

dan IImu Pendidikan

Universitas PGRI Palembang

\section{Gambar Cover:}

Pohon Kalpataru

Candi Prambanan

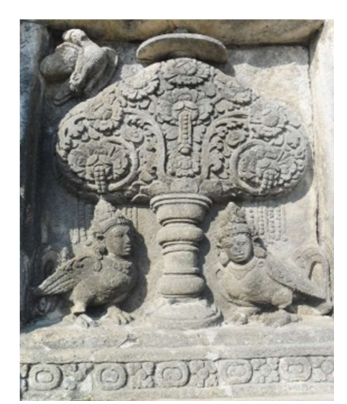

Koleksi: Muhamad Idris 


\section{DAFTAR ISI}

Pengaruh Model Pembelajaran Student Facilitator and Explaining Terhadap Hasil Belajar Siswa Pada Mata Pelajaran Sejarah Kelas X di SMA Negeri 3 Palembang

Sarinah, Nur Ahyani, Ahmad Zamhari 83-89

Pengaruh Model Pembelajaran Berbasis Masalah (PBM) Terhadap Hasil Belajar Siswa Pada Mata Pelajaran IPS Terpadu (Sejarah) Kelas VIII di SMP Negeri 2 Palembang

Neka Dapistri, Nur Ahyani, Ahmad Zamhari..... 90-95

Penerapan Media Pembelajaran Menggunakan Google Earth Dalam Materi Kondisi Masyarakat Indonesia Pada Masa Penjajahan Terhadap Hasil Belajar Siswa Pada Mata Pelajaran IPS Terpadu di SMP Quraniah Palembang

Tri Nur Ariani, Eva Dina Chairunisa, Ida Suryani $96-101$

Perkembangan Sosial Budaya Suku Jawa di Desa Kapasan Tegalrejo BK X Kecamatan Belitang Kabupaten Ogan Komering Ulu Timur Sebagai Sumber Pembelajaran Sejarah di SMA Muhammadiyah 2 Karang Tengah

Ratna Puspita Dewi, Sukardi, Mirza Fansyuri. $102-109$

Pengembangan E-Modul Pembelajaran Sejarah Tokoh-Tokoh Pembangunan Pacsa Kemerdekaan di Sumatera Selatan

Susi Susanti, Eva Dina Chairunisa 110-113

Peran Pendidikan Sejarah Dalam Membentuk Karakter Bangsa

Sukardi, Jeki Sepriady $114-117$

Sejarah Pengajaran Mantra Melayu di Tengah Perubahan Masyarakat Besemah Muhamad Idris, Eva Dina Chairunisa, Jeki Sepriady..... 118-127

Pengembangan Media Audio Visual Sejarah Kolonialisme Barat di Indonesia Materi Benteng Marlborough Bengkulu

Hamza Kurniawan. 128-135 
Kalpataru, Volume 6, Nomor 2, Desember 2020 (83-89)

\title{
PENGARUH MODEL PEMBELAJARAN STUDENT FACILITATOR AND EXPLAINING TERHADAP HASIL BELAJAR SISWA PADA MATA PELAJARAN SEJARAH KELAS X DI SMA NEGERI 3 PALEMBANG
}

\author{
Sarinah \\ Mahasiswa Program Studi Pendidikan Sejarah, FKIP Universitas PGRI Palembang \\ Email: ssarinah476@gmail.com \\ Nur Ahyani \\ Dosen Program Studi Pendidikan Sejarah, FKIP Universitas PGRI Palembang \\ Email: nurahyani_sj@univpgri-palembang.ac.id \\ Ahmad Zamhari \\ Dosen Program Studi Pendidikan Sejarah, FKIP Universitas PGRI Palembang \\ Email: ahmadzamhari_sj@univpgri-palembang.ac.id
}

\begin{abstract}
ABSTRAK
Model dalam pembelajaran memiliki fungsi sebagai jembatan atau media tranformasi pelajaran terhadap proses belajar siswa secara efektif, sesuai dengan materi yang disampaikan dalam pencapaian tujuan pembelajaran. Masalah dalam penelitian ini adalah adakah pengaruh model pembelajaran student facilitator and explaining terhadap hasil belajar siswa pada mata pelajaran sejarah kelas X di SMA Negeri 3 Palembang. Tujuan penelitian ini adalah untuk mengetahui ada atau tidaknya pengaruh model pembelajaran student facilitator and explaining terhadap hasil belajar siswa pada mata pelajaran sejarah kelas X di SMA Negeri 3 Palembang. Populasi dalam penelitian ini adalah siswa kelas $X$ di SMA Negeri 3 Palembang dan sampel penelitian ini adalah siswa kelas $X .7$ dengan jumlah siswa 36 orang sebagai kelas eksperimen dan kelas $X .8$ dengan jumlah siswa 36 orang (50) sebagai kelas kontrol. Dari hasil penelitian terbukti bahwa "ada pengaruh penerapan model pembelajaran student facilitator and explaining terhadap hasil belajar siswa pada mata pelajaran sejarah kelas $X$ di SMA Negeri 3 Palembang". Dengan nilai rata-rata kelas eksperimen 79,75, sedangkan kelas kontrol 70,86. Sehingga didapat $t_{\text {hitu }}=4,728$ dan $t_{\text {tabel }}=1,66691$. Dengan ini dapat disimpulkan $t_{\text {hitung }} \geq t_{\text {tabel }}$ sehingga $H_{o}$ ditolak dan $H_{a}$ diterima.
\end{abstract}

Kata Kunci: Model Pembelajaran, Student Facilitator and Explaining, Hasil Belajar.

\section{A. PENDAHULUAN}

Pendidikan adalah proses upaya meningkatkan nilai peradaban individu atau masyarakat dari suatu keadaan tertentu menjadi suatu keadaan yang lebih baik, dan prosesnya melalui penelitian, pembahasan, atau merenungkan tentang masalah atau gejala-gejala perbuatan mendidik. Pendidikan juga merupakan kegiatan membudayakan manusia/membuat orang berbudaya. Budaya adalah segala hasil pikiran, kemauan, perasaan, dan karya manusia secara individu/kelompok untuk meningkatkan kehidupan manusia (budaya bisa dalam bentuk benda-benda nyata dan bisa juga bersifat abstrak) (Neolaka, 2017:14-9). Praktik-praktik pengajaran yang berlaku selama ini sering dicap sebagai pelajaran hafalan. Hal ini kadang mengakibatkan kebosanan pada peserta didik yang berdampak pada kurangnya pemahaman siswa terhadap materi yang disampaikan sehingga hasil belajarnya kurang maksimal (Widja, 1989:103).

Berdasarkan observasi yang telah dilakukan oleh peneliti di SMA Negeri 3 Palembang dalam pelaksanaan pembelajaran guru menggunakan metode ceramah, tanya jawab dan diskusi. Sehingga banyak siswa yang tidak aktif, kurang percaya diri dalam menyampaikan pendapat mereka. Dalam proses pembelajaran berlangsung terdapat siswa yang memperhatikan guru saat menyampaikan materi, ada sebagian siswa yang tidak memperhatikan, serta kurang 
memiliki keterampilan dalam menyelesaikan soal, hal inilah yang cenderung dapat menurunkan hasil belajar siswa. Salah satu model pembelajaran yang bisa membuat dan membawa siswa lebih aktif adalah model pembelajaran Student Facilitator And Explaining. Dalam model pembelajaran ini dimana guru memberi kesempatan kepada siswa untuk bisa berperan aktif dalam proses pembelajaran dengan menyampaikan pendapat serta gagasan kepada siswa lainnya sesuai dengan materi yang sudah dipahami.

Dari uraian di atas, peneliti tertarik mengadakan penelitian yang berjudul "Pengaruh Model Pembelajaran Student Facilitator And Explaining terhadap Hasil Belajar Siswa Pada Mata Pelajaran Sejarah Kelas X di SMA Negeri 3 Palembang".

Berdasarkan latar belakang yang telah diuraikan diatas maka rumusan masalah dalam penelitian ini adalah "Adakah Pengaruh Model Pembelajaran Student Facilitator And Explaining terhadap Hasil Belajar Siswa Pada Mata Pelajaran Sejarah Kelas X di SMA Negeri 3 Palembang?".

Sesuai dengan rumusan masalah di atas maka tujuan dalam penelitian ini adalah untuk mengetahui ada atau tidaknya pengaruh model pembelajaran Student Facilitator And Explaining terhadap hasil belajar siswa pada mata pelajaran sejarah kelas $X$ di SMA Negeri 3 Palembang.

\section{B. METODE PENELITIAN}

Metode penelitian merupakan kumpulan prosedur, skema, dan algoritma yang digunakan sebagai alat ukur atau intrumen dalam pelaksanaan penelitian. Semua metode yang digunakan peneliti selama penelitian disebut sebagai penelitian (Timotus, 2017:5).

Metode penelitian yag digunakan adalah model Quasi Exsperiment Design. Desain ini mempunyai kelompok kontrol, tetapi tidak dapat berfungsi sepenuhnya untuk mengontrol variabel-variabel luar yang mempengaruhi pelakasanaan eskperimen. Untuk pelaksanaan penelitian ini diperlukan dua kelompok yang diberi perlakuan berbeda. Kelompok pertama adalah kelompok yang diajar menggunakan model pembelajaran Student Facilitator And
Explaining (kelas eksperimen) dan kelompok kedua diajarkan dengan model ceramah (kelas kontrol). Bentuk design yang digunakan dalam penelitian yaitu Nonequevalent Control Group Design (Sugiyono, 2017:77). Rancangan ini terdiri atas dua kelompok yang keduanya ditentukan secara acak. Sebelum dilakukan penelitian kedua kelompok diberikan tes awal (Pretest) dan setelah dilakukan penelitian kedua kelompok diberikan tes akhir (Postest), untuk bentuk gambar 1 desain ini sebagai berikut (Sugiyono, 2017:79).

Tabel 3.1

\section{Desain Penelitian Nonequevalent Control Group Design}

\begin{tabular}{|cccc|}
\hline $\mathbf{E}$ & $\mathbf{O}_{1}$ & $\mathrm{X}$ & $\mathbf{O}_{2}$ \\
$\mathrm{~K}$ & $\mathbf{O}_{3}$ & & $\mathbf{O}_{4}$ \\
\hline
\end{tabular}

Keterangan:

E : kelas eksperimen yang diterapkan model pembelajaran student facilittaor and explaining.

$\mathrm{K}$ : kelas kontrol yang diterapkan dengan ceramah.

$\mathrm{X}$ : kelompok kelas eksperimen atau kontrol yang dipilih secara acak.

$\mathrm{O}_{1}$ : pretest yang diberikan pada kelas eksperimen.

$\mathrm{O}_{2}$ : adalah posttest yang diberikan pada kelas kontrol.

$\mathrm{O}_{3}$ : pretest yang diberikan pada kelas eksperimen.

$\mathrm{O}_{4}$ : posttest yang diberikan pada kelas kontrol.

Populasi dalam penelitian ini adalah siswa kelas $X$ SMA Negeri 3 Palembang berjumlah 12 kelas dengan jumlah siswa kurang lebih 432 orang. Pengambilan sampel dalam penelitian ini diambil secara acak (simple random sampling) dari kelas X.1 sampai $X .12$ sehingga peneliti mengambil sampel di kelas X MIPA 7 dengan jumlah siswa 36 orang yang dijadikan kelas eksperimen dan kelas X MIPA 8 dengan jumlah 36 orang siswa dijadikan kelas kontrol. 
Teknik pengumpulan data dalam penelitian ini adalah menggunakan teknik tes dan observasi. Tes merupakan serentetan atau latihan yang digunakan untuk mengukur keterampilan, pengetahuan, sikap, intelegensi, kemampuan atau bakat yang dimiliki oleh individu atau kelompok (Riyanto, 2010:103). Tes disini digunakan untuk mengukur mengukur hasil belajar pada aspek kognitif. Instrumen tes yang digunakan dalam penelitian ini berbentuk essay.

Teknik analisis data yang digunakan untuk meningkatkan hasil belajar siswa dalam penelitian ini adalah dengan menghitung ratarata dan simpangan baku, uji normalitas data, uji homogenitas dan uji hipotesis. Uji coba instrumen dilaksanakan tanggal 15-19 Juni 2020 di kelas X MIPA 7 dan X MIPA 8 SMA Negeri 3 Palembang, soal uji coba instrumen essay berjumlah 5 soal.

\section{HASIL DAN PEMBAHASAN}

1. Hasil Penelitian

Penelitian ini dilaksanakan di dua kelas sampel, yaitu kelas eksperimen dan kelas kontrol. Sampel dalam penelitian ini yaitu siswa kelas X MIPA 7 dan kelas X MIPA 8 Sekolah Menengah Atas Negeri 3 Palembang. Dimana kelas X MIPA 7 sebagai kelas eksperimen dan kelas X MIPA 8 kelas kontrol. Pada kelas eksperimen, yaitu kelas $X .7$ proses pembelajarannya menggunakan model pembelajaran student facilitator and explaining, sedangkan pada kelas kontrol, yaitu kelas X.8 proses pembelajaranya menggunakan metode ceramah. Materi yang dibahas adalah tentang proses masuk dan berkembangnya agama dan kebudayaan Islam di Indonesia serta Salurasaluran penyebaran Islam di Indonesia.

Uji normalitas data bertujuan untuk mengetahui apakah hasil nilai siswa tersebut berdistribusi normal atau tidak.

Dari hasil tes yang diperoleh siswa kelas $X$ MIPA 7 dan $X$ MIPA 8 baik dengan menggunakan model pembelajaran student facilitator and explaining maupun tidak menggunakan model pemeblajaran dengan materi proses masuknya agama dan kebudayaan Islam ke Indonesia, dapat dilihat pada tabel sebagai berikut:
Tabel 3.2

Data Nilai Hasil Tes Kelas Kontrol dan

Eksperimen

\begin{tabular}{|c|c|c|c|c|}
\hline Kelas & $\mathbf{N}$ & $\begin{array}{c}\text { Nilai } \\
\text { Tertinggi }\end{array}$ & $\begin{array}{c}\text { Nilai } \\
\text { Terendah }\end{array}$ & $\mathbf{x}$ \\
\hline $\begin{array}{c}\text { Eksperi } \\
\text { men }\end{array}$ & 36 & 95 & 60 & 80 \\
\hline Kontrol & 36 & 85 & 55 & 69,75 \\
\hline
\end{tabular}

Berdasarkan analisis data hasil tes akhir kelas kontrol yang menggunakan strategi atau metode ceramah, dapat diketahui bahwa nilai tertingginya adalah 85 yang didapat 5 orang siswa dan nilai terendahnya adalah 55 yang didapat oleh 5 orang siswa. Sedangkan penilaian tes akhir latihan pada kelas eksperimen yang menggunakan model pembelajaran student facilitator and explaining dalam materi proses masuknya agama dan kebudayaan Islam ke Indonesia dapat diketahui bahwa nilai tertingginya adalah 95 yang didapat 10 orang siswa dan nilai terendahnya adalah 60 yang didapat oleh 3 orang siswa.

\section{a) Uji Normalitas Data}

Uji Normalitas Data Kelas Kontrol

1. Rentang kelas

Rentang = Data terbesar - data terkecil

$\mathrm{R}=85-55$

$$
=30
$$

2. Banyak kelas interval

$$
b=1+(3,3) \log 36
$$

$=1+3,3 \log 36$

$=1+3,3(1,55)$

$=1+5,11$

$=6,11$ (dibulatkan jadi 6$)$

3. Menentukan Panjang Kelas Interval

$$
\begin{aligned}
P & =\frac{\text { rentang }}{\text { jumlah kelas }} \\
& =\frac{30}{12} \\
& =2.5(\text { dibulatkan menjadi } 3)
\end{aligned}
$$

Tabel 3.3

DISTRIBUSI FREKUENSI NILAI TES AKHIR KELAS KONTROL 
Kalpataru, Volume 6, Nomor 2, Desember 2020 (83-89)

\begin{tabular}{|c|c|c|c|c|c|}
\hline $\begin{array}{c}\text { Interval } \\
\text { Nilai Tes }\end{array}$ & $\boldsymbol{f}_{\boldsymbol{i}}$ & $\boldsymbol{x}_{\boldsymbol{i}}$ & $\boldsymbol{f}_{\boldsymbol{i}} \boldsymbol{x}_{\boldsymbol{i}}$ & $\boldsymbol{x}_{\boldsymbol{i}}^{\mathbf{2}}$ & $\boldsymbol{f}_{\boldsymbol{i}} \cdot \boldsymbol{X}_{\boldsymbol{i}}^{\mathbf{2}}$ \\
\hline $\mathbf{5 5 - 5 7}$ & 5 & 56 & 280 & 3136 & 15680 \\
\hline $\mathbf{5 8 - 6 0}$ & 7 & 59 & 413 & 3481 & 24367 \\
\hline $\mathbf{6 1 - 6 3}$ & 3 & 62 & 186 & 3844 & 11532 \\
\hline $\mathbf{6 4 - 6 6}$ & 3 & 65 & 195 & 4225 & 12675 \\
\hline $\mathbf{6 7 - 6 9}$ & 0 & 68 & 0 & 4624 & 0 \\
\hline $\mathbf{7 0 - 7 2}$ & 1 & 71 & 71 & 5041 & 5041 \\
\hline $\mathbf{7 3 - 7 5}$ & 4 & 74 & 296 & 5476 & 21904 \\
\hline $\mathbf{7 6 - 7 8}$ & 0 & 77 & 0 & 5929 & 0 \\
\hline $\mathbf{7 9 - 8 1}$ & 8 & 80 & 640 & 6400 & 51200 \\
\hline $\mathbf{8 2 - 8 4}$ & 0 & 83 & 0 & 6889 & 0 \\
\hline $\mathbf{8 5 - 8 7}$ & 5 & 86 & 430 & 7396 & 36980 \\
\hline Jumlah & 36 & 81 & 2551 & 56441 & 179379 \\
\hline
\end{tabular}

\section{UJI NORMALITAS}

Menentukan kemiringan kurva dengan menggunakan rumus:

$$
\begin{aligned}
K_{m} & =\frac{X-M_{O}}{S} \\
K_{m} & =\frac{70,86-80}{-6,29} \\
K_{m} & =\frac{-9,14}{-6,29} \\
=1,45 &
\end{aligned}
$$

Karena nilai $K_{m}$ kelas kontrol sebesar 1,45 ini terletak antara $(-1)$ dan $(+1)$, maka data tersebut terdistribusi normal.

\section{Menentukan Nilai Rata-rata}

$$
\begin{aligned}
\bar{x} & =\frac{\sum f_{i^{x_{i}}}}{\sum f_{i}} \\
& =\frac{2551}{36} \\
& =70,86
\end{aligned}
$$

5. Menentukan Nilai Modus

$$
\begin{aligned}
M_{O} & =b+p\left[\frac{b}{b_{1}+b_{2}}\right] \\
& =78,5+\left(\frac{8}{8+8}\right) 3 \\
& =78,5+\left(\frac{8}{16}\right) 3 \\
& =78,5+1,5 \\
& =80
\end{aligned}
$$

Jadi, nilai rata-rata tes akhir siswa

pada kelas kontrol adalah 80 dikategorikan baik.

6. Varians

$$
\text { Varians: } \begin{aligned}
& S^{2}=\frac{n \sum f_{i} x_{i}{ }^{2}-\left(\sum f_{i} x_{i}\right)^{2}}{n(n-1)} \\
S^{2} & =\frac{36.179379-(2551)^{2}}{36(36-1)} \\
S^{2} & =\frac{6457644-6507601}{36(35)} \\
S^{2} & =\frac{-49957}{1260} \\
S^{2} & =-39,64 \\
S & =-\sqrt{39,64} \\
S & =-6,29
\end{aligned}
$$

Jadi, nilai varians adalah - 39,64 dan simpangan baku pada kelas kotrol adalah - 6,29.

\section{b) Uji Normalitas Data Kelas Eksperimen \\ 1. Rentang Nilai \\ Rentang $=$ Data terbesar - data terkecil \\ $\mathrm{R}=95-60$ \\ $=35$}

\section{Banyak kelas interval}

$b=1+(3,3) \log n$

$=1+3,3 \log 36$

$=1+3,3(1,55)$

$=1+5,11$

= 6,11 (dibulatkan jadi 6)

3. Menentukan Panjang Kelas Interval

$$
\begin{aligned}
P & =\frac{\text { rentang }}{\text { banyak kelas }} \\
= & \frac{35}{12} \\
= & 2,91 \text { (dibulatkan menjadi } 3)
\end{aligned}
$$

Tabel 3.4

DISTRIBUSI FREKUENSI NILAI TES AKHIR KELAS EKSPERIMEN

\begin{tabular}{|c|c|c|c|c|c|}
\hline $\begin{array}{c}\text { Interval } \\
\text { Nilai Tes }\end{array}$ & $\boldsymbol{f}_{\boldsymbol{i}}$ & $\boldsymbol{x}_{\boldsymbol{i}}$ & $\boldsymbol{f}_{\boldsymbol{i}} \boldsymbol{x}_{\boldsymbol{i}}$ & $\boldsymbol{x}_{\boldsymbol{i}}^{\mathbf{2}}$ & $\boldsymbol{f}_{\boldsymbol{i}} \cdot \boldsymbol{X}_{\boldsymbol{i}}^{\mathbf{2}}$ \\
\hline $\mathbf{6 0 - 6 2}$ & 4 & 61 & 244 & 3721 & 14884 \\
\hline $\mathbf{6 3 - 6 5}$ & 3 & 64 & 192 & 4096 & 12288 \\
\hline $\mathbf{6 6 - 6 8}$ & 0 & 67 & 0 & 4489 & 0 \\
\hline $\mathbf{6 9 - 7 1}$ & 4 & 70 & 280 & 4900 & 19600 \\
\hline $\mathbf{7 2 - 7 4}$ & 0 & 73 & 0 & 5329 & 0 \\
\hline $\mathbf{7 5 - 7 7}$ & 4 & 76 & 304 & 5776 & 23104 \\
\hline $\mathbf{7 8 - 8 0}$ & 4 & 79 & 316 & 6241 & 24964 \\
\hline $\mathbf{8 1 - 8 3}$ & 0 & 82 & 0 & 6724 & 0 \\
\hline $\mathbf{8 4 - 8 6}$ & 7 & 85 & 595 & 7225 & 50575 \\
\hline
\end{tabular}


Kalpataru, Volume 6, Nomor 2, Desember 2020 (83-89)

\begin{tabular}{|c|c|c|c|c|c|}
\hline $\begin{array}{c}\text { Interval } \\
\text { Nilai Tes }\end{array}$ & $\boldsymbol{f}_{\boldsymbol{i}}$ & $\boldsymbol{x}_{\boldsymbol{i}}$ & $\boldsymbol{f}_{\boldsymbol{i}} \boldsymbol{x}_{\boldsymbol{i}}$ & $\boldsymbol{x}_{\boldsymbol{i}}^{\mathbf{2}}$ & $\boldsymbol{f}_{\boldsymbol{i}} \cdot \boldsymbol{X}_{\boldsymbol{i}}^{\boldsymbol{2}}$ \\
\hline $\mathbf{8 7 - 8 9}$ & 0 & 88 & 0 & 7744 & 0 \\
\hline $\mathbf{9 0 - 9 2}$ & 0 & 91 & 0 & 8281 & 0 \\
\hline $\mathbf{9 3 - 9 5}$ & 10 & 94 & 940 & 8836 & 88360 \\
\hline Jumlah & 36 & 930 & 2871 & 73362 & 233775 \\
\hline
\end{tabular}

$$
\begin{aligned}
K_{m} & =\frac{-15,75}{11,72} \\
& =-1,34
\end{aligned}
$$

Karena nilai $K_{m}$ kelas eksperimen sebesar - 1,34 ini terletak antara (-1) dan (+1), maka data tersebut trdistribusi normal.

Hasil pengujian hipotesis dalam penelitian ini adalah dengan menggunakan rumus uji-t maka didapat nilai $t_{\text {tabel }}$ untuk $\mathrm{dk}=$ $36+36-2=70$ diperoleh nilai $t_{\text {tabel }}$ sebesar 1,66691 dengan menggunakan dasar taraf signifikan $a=0,05$ jadi taraf pengaruh model pembelajaran Student Facilitator And Explaining ini 95\% mempengaruhi dan apabila taraf signifikan diambil $a=0,01$ itu artinya model ini pun juga masih sangat mempengaruhi terhadap hasil belajar siswa. Jadi $t_{h i} \geq t_{\text {tabel }}$ sehingga $H_{o}$ ditolak dan $H_{a}$ diterima yang artinya "Ada pengaruh yang signifikan dari Model Pembelajaran Student Facilitator and Explaining terhadap Hasil Belajar Siswa Pada Mata Pelajaran Sejarah Kelas X di SMA Negeri 3 Palembang.

Uji homogenitas dalam penelitian ini pada kelas eksperimen adalah 95,5 dikategorikan sangat baik.

\section{Varians}

$$
\text { Varians : } \begin{aligned}
S^{2} & =\frac{n \sum f_{i} x_{i}{ }^{2}-\left(\sum f_{i} x_{i}\right)^{2}}{n(n-1)} \\
S^{2} & =\frac{36.233775-(2871)^{2}}{36(36-1)} \\
S^{2} & =\frac{8415900-8242641}{36(35)} \\
S^{2} & =\frac{173259}{1260} \\
S^{2} & =137,507 \\
S & =\sqrt{137,507} \\
S & =11,72
\end{aligned}
$$

yaitu dengan menghitung $f_{\text {tabel }}$ dengan $d b_{\text {pembilang }}=36-1=35$ (untuk varian terbesar) dan $d b_{\text {penyebut }}=36-1=35$ (varian untuk terkecil), serta taraf signifikan $(a)=0,05$ maka diperoleh $f_{\text {tabel }}=1,76$. Jadi perbandingan antara $f_{\text {hitung }}=3,47>f_{\text {tabel }}=$ 1,76, maka dapat disimpulkan $H_{a}$ diterima atau ada perbedaan model pembelajaran Student Facilitator And Explaining, berarti data tersebut memiliki varian yang sama atau homogen.

\section{Pembahasan}

Dari hasil analisis data penelitian yang dan simpangan baku pada kelas eksperimen adalah 11,72.

\section{UJI NORMALITAS}

Menentukan kemiringan kurva dengan menggunakan rumus :

$$
\begin{aligned}
K_{m} & =\frac{X-M_{O}}{S} \\
K_{m} & =\frac{79,75-95,5}{11,72}
\end{aligned}
$$

didapatkan, maka pembahasan dalam penelitian ini adalah sebagai berikut:

Penelitian ini adalah tentang pengaruh model pembelajaran Student Facilitator and Explaining terhadap hasil belajar siswa. Pengambilan sampel dalam penelitian ini menggunakan teknik Quasi Eksperimen Design. Dalam pengambilan data dilakukan dengan secara acak sederhana (simple random sampling), yaitu teknik pengambilan sampel yang memberikan peluang yang sama 


\section{Kalpataru, Volume 6, Nomor 2, Desember 2020 (83-89)}

bagi setiap unsur (anggota) populasi untuk dipilih menjadi anggota sampel. Dalam penelitian ini menggunakan dua kelas sampel yaitu X MIPA 7 sebagai kelas eksperimen yang berjumlah 36 orang siswa dan X MIPA 8 sebagai kelas kontrol yang berjumlah 36 orang siswa.

Berdasarkan data hasil penelitian yang dilakukan peneliti dari pertemuan pertama sampai pertemuan terakhir, hasil nilai rata-rata tes akhir pada kelas eksperimen yaitu 79,75 Siswa yang mendapatkan nilai tertinggi yaitu 95 didapatkan 10 orang dan nilai terendah 60 didapat 3 orang. Sedangkan pada tes awal nilai tertinggi 80 didapatkan 6 orang siswa dan terendah 45 adalah 7 orang siswa, jadi terbukti penggunaan model pembelajaran Student Facilitator and Explaining dapat meningkatkan hasil belajar siswa.

Kemudian dengan melalui pembelajaran menggunakan model pembelajaran Student Facilitator and Explaining terhadap materi sejarah kelas $X$ dikategorikan sangat baik. Hal ini dapat dilihat dari perolehan mengenai nilai hasil belajar siswa sebelum dan sesudah mendapatkan pembelajaran menggunakan model pembelajaran Student Facilitator and Explaining, peneliti melihat adanya peningkatkan hasil belajar siswa setiap kali pertemuan pembelajaran yang dilihat dari perolehan nilai soal latihan siswa.

Contohnya seperti penelitian yang dilakukan oleh Anda Weni dengan judul pengaruh penerapan model Student Facilitator and Explaining terhadap hasil belajar siswa pada mata pelajaran IPS (Sejarah) di kelas VII SMP Negeri 3 Sungai Rotan, penelitian Hasanudin dengan judul penerapan model pembelajaran Student Facilitator And Explaining untuk meningkatkan hasil belajar dan aktivitas siswa materi gas ideal di kelas XI IPA-1 SMA Negeri 1 Sungai Ambawang, penelitian oleh Indah Lestari dkk dengan judul pengaruh model pembelajaran Student Facilitator And Explaining terhadap hasil belajar IPA kelas V, kemudian penelitian oleh Agus Saifuddin dkk dengan judul penerapan model pembelajaran Student Facilitator And Explaining (SFE) dengan menggunakan peta konsep untuk meningkatkan keaktifan dan prestasi belajar siswa pada mata pelajaran ekonomi kelas $x$ lintas minat ekonomi di SMA Negeri 02 Batu.

Setelah menghitung nilai normalitas dan hipotesis dari hasil perhitungan terbukti berdistribusi normal, maka data tersebut dapat diolah dengan uji stastitik yaitu dengan uji-t satu pihak. Dari hasil perhitungan uji-t diperoleh nilai $t_{\text {hit }}=4,728$ dan $t_{\text {tabel }}=1,66691$ Dengan demikian berarti $t_{\text {hitu }} \geq t_{\text {tabel }}$ sehingga $H_{o}$ ditolak dan $H_{a}$ diterima.

Dari hal tersebut maka dapat disimpulkan bahwa adanya pengaruh dari Model Pembelajaran Student Facilitator and Explaining terhadap Hasil Belajar Siswa Pada Mata Pelajaran Sejarah Kelas X di SMA Negeri 3 Palembang.

\section{SIMPULAN}

Berdasarkan hasil analisis dan pembahasan mengenai pengaruh penerapan model student facilitator and explaining terhadap hasil belajar siswa pada mata pelajaran sejarah kelas $X$ di SMA Negeri 3 Palembang dapat disimpulkan bahwa penelitian yang telah dilakukan di SMA Negeri 3 Palembang dengan menerapkan model pembelajaran Student Facilitator And Explaining diperoleh nilai rata-rata kelas eksperimen 79,75 , sedangkan nilai rata-rata untuk kelas kontrol diberi perlakuan metode ceramah 70,86.

Oleh karena itu adanya pengaruh dalam penerapan model pembelajaran student facilitator and explaining terhadap hasil belajar siswa pada mata pelajaran sejarah kelas $X$ di SMA Negeri 3 Palembang dengan menggunakan dasar taraf signifikan $a=0,05$ jadi taraf pengaruh model pembelajaran Student Facilitator And Explaining ini 95\% mempengaruhi dan apabila taraf signifikan diambil $a=0,01$ itu artinya model ini pun juga masih sangat mempengaruhi terhadap hasil belajar siswa. Oleh karena itu hasil pengujian hipotesis dengan menggunakan rumus uji-t didapat nilai $t_{\text {tabel }}$ untuk $\mathrm{dk}=36+36-2=70$ diperoleh nilai $t_{\text {tabel }}$ sebesar 1,66691 , jadi diketahui $t_{\text {hitung }}=4,728>t_{\text {tabel }}=1,66691$, maka $H_{o}$ di tolak dan $H_{a}$ di terima berarti ini menyatakan bahwa hasil yang positif, maka 
model pembelajaran Student Facilitator And Explaining dapat diterima.

\section{DAFTAR PUSTAKA}

Neolaka, Amos, dkk. 2017. Landasan Pendidikan (Dasar Pengenalan Diri Sendiri Menuju Perubahan Hidup). Depok: Kencana.

Riyanto, Yatim. 2009. Paradigma Baru Pembelajaran: Sebagai Referensi bagi Pendidik dalam Implementasi Pembelajaran yang Efektif dan Berkualitas. Jakarta: Prenada Media Group.

Sugiyono. 2017. Statistika Untuk Penelitian. Bandung: Penerbit Alfabeta.

Timotius, Kris. 2017. Pengantar Metodologi Penelitian. Yogyakarta: Penerbit ANDI.

Widja, I Gede. 1989. Dasar-Dasar Pengembangan Strategi serta Metode Pengajaran Sejarah. Jakarta: Departemen Pendidikan dan Kebudayaan Direktorat Jenderal Pendidikan Tinggi Proyek Lembaga Pendidikan Tenaga Kependidikan. 


\section{KETENTUAN PENULISAN ARTIKEL JURNAL KALPATARU}

1. Naskah berbahasa Indonesia yang disempurnakan bertemakan kesejarah yang meliputi hasil penelitian sejarah, pengajaran sejarah dan penelitian kebudayaan.

2. Naskah harus asli dan belum pernah dimuat dalam media lain. Naskah dapat berupa hasil penelitian/artikel kajian konseptual yang ditulis oleh perorangan dan atau kelompok.

3. Naskah ditulis dengan cara-cara yang sesuai dengan ketentuan penulisan artikel ilmiah menggunakan bahasa Indonesia yang baku, berupa ketikan, beserta soft file dalam CD-RW atau dengan mengirimkan email pada redaksi jurnal Kalpataru dengan alamat jurnalkalpatarusejarah@gmail.com, spasi tunggal, jenis huruf arial narrow ukuran 12, dengan panjang naskah antara 8-15 halaman pada kertas A4.

4. Artikel hasil penelitian memuat:

JUDUL

Nama Penulis

Abstrak

A. PENDAHULUAN

B. METODE PENELITIAN

C. HASIL DAN PEMBAHASAN

D. SIMPULAN

DAFTAR PUSTAKA
: XXX (HURUF KAPITAL)

: (disertai jabatan, institusi, dan email)

: (Bahasa Indonesia yang memuat 100-200 kata diikuti kata kunci, dengan jenis huruf arrial narrow dan ukuran huruf 11 serta dicetak miring).

: (memuat latar belakang masalah, tinjauan pustaka secara ringkas, masalah penelitian, dan tujuan penelitian).

5. Artikel Kajian Konseptual memuat:

JUDUL

Nama Penulis

Abstrak

PENDAHULUAN

Sub Judul

Simpulan

DAFTAR PUSTAKA
: (berisi simpulan).

: (berisi pustaka yang dirujuk dalam uraian naskah).

6. Referensi sumber dalam teks artikel ditulis dengan menggunakan side note, contoh (Jalaludin, 1991:79); sementara penulisan daftar pustaka disusun dengan ketentuan. Nama pengarang. Tahun terbit. Judul (dicetak miring). Kota terbit: Nama Penerbit. Contoh: Koentjaraningrat. 2010. Manusia dan Kebudayaan di Indonesia. Jakarta: Djambatan. Daftar pustaka hanya memuat pustaka/sumber yang dirujuk dalam uraian dan disusun menurut abjad tanpa nomor urut.

7. Naskah yang dimuat akan disunting kembali oleh redaksi tanpa mengubah isinya.

8. Naskah yang ditolak (tidak bisa dimuat) akan dikirim kembali ke penulis dengan pemberitahuan tertulis dari redaksi atau melalui email.

9. Penulis yang naskahnya dimuat akan mendapat 1 (satu) majalah nomor yang bersangkutan.

10.Kontak person: Muhamad Idris (081271498618); Eva Dina Chairunisa (082281267851); Jeki Sepriady (085269261780). 